\title{
Comparative Study of Nutritional Values of Edible Viscera Mediterranean Mollusks Gastropods hexaplex trunculus and bolinus brandaris. Hypobranchial glands inhibit Human Glioblastoma U87 Tumor Cells Adhesion and Proliferation
}

\author{
Chabchoub Ellouz Soufia ${ }^{1,2,3 *}$, Ben Mabrouk Hazem ${ }^{3}$, Baroudi Olfa ${ }^{3}$, \\ Ayed Naceur ${ }^{1}$, El Ayeb Mohamed ${ }^{3}$, Marrakchi Naziha ${ }^{3}$ \\ ${ }^{1}$ Carthage University Research Unit of Industrial Organic Chemistry and Food 00UR1201; \\ National Institute of Applied Sciences and Technology, PO Box 676; 1080 Tunis, Tunisia \\ ${ }^{2}$ Tunis University El Manar Higher Institute of Medical Biotechnology of Tunis, \\ Laboratory of Biophysics and Medical Technology Tunis Tunisia \\ ${ }^{3}$ Unis University El manar Laboratory of venoms and therapeutic bimolecular. Pastor Institute of Tunis, Tunisia \\ ${ }^{4}$ Tunis University El Manar Laboratories of Genetics, Immunology and Human Pathology. Faculty of Sciences Tunis Tunisia \\ *Corresponding author E-mail: soufiaellouzchabchoub@yahoo.fr
}

Copyright $\odot 2014$ Chabchoub Ellouz Soufia et al. This is an open access article distributed under the Creative Commons Attribution License, which permits unrestricted use, distribution, and reproduction in any medium, provided the original work is properly cited.

\begin{abstract}
This study aims first to identify nutritionals values of edible mix Muscle Hypobranchial Gland MHG, fresh and cooked extract from internal organs of two gastropods mollusks Hexaplex trunculus HT and Bolinus brandaris BB males and females. Second, to characterize and evaluate the role of hypobranchial glands extract HBGE of these mollusks gastropods on adhesion and cell proliferation of human glioblastoma tumor cells U87. Biochemical analyzes show that fresh MHG, HT and BB are rich in Water $82.52 \%$ in HT males, $79.23 \%$ in HT females. They are rich in Proteins $12.79 \%$ in BB females to $10.30 \%$ in HT females) and in Energy value $79.14 \mathrm{kcal}$ in BB females to $69.48 \mathrm{kcal}$ in HT males. They contain fewer carbohydrates $6.27 \%$ in BB males to $5.40 \%$ in HT males, less total ash $1.52 \%$ in HT females to $1.11 \%$ in HT males and less lipids $2.55 \%$ in HT females to $0.74 \%$ in BB males. Further, HBGE of HT inhibited U87 cell adhesion to fibrinogen at $15 \mathrm{mg} / \mathrm{ml}$. This inhibition was accelerated at $20 \mathrm{mg} / \mathrm{ml}$ without exceeding $50 \%$ of inhibition. HBGE of BB reduced glioblastoma cells adhesion upon to $5 \mathrm{mg} / \mathrm{ml}$ with IC50 values of $9 \mathrm{mg} / \mathrm{ml}$ for male and $20 \mathrm{mg} / \mathrm{ml}$ for female. U87 cells treated with HBGE HT and BB decreased significantly cell proliferation by $50 \%$ and $70 \%$ respectively. Our results lead us to encourage the use of these marine snails, source of protein and high energy values. Moreover, HBGE may have the potential to serve as a template for future anticancer-drug development.
\end{abstract}

Keywords: Mix Muscle- Hypobranchial Gland, Hexaplex Trunculus, Bolinus Brandaris, Nutritional Values, Glioblastoma U87 Cells, Cell Adhesion and Proliferation.

\section{Introduction}

Some marine, mollusks, gastropods were particularly exploited to extract a pigment known as Purple [1]. Indeed, shells of broken Hexaplex trunculus and Bolinus brandaris were found in the monuments and tombs of Carthage in colorful purple clay, indicating a highly developed art purple industry [2]. Therefore, hypobranchial or purple gland of hexaplex have attracted the attention of zoologists and biochemists for his secrete chromogenic aspect which, in presence of light and air are oxidized to an intense fast purple dye known as Tyrant purple [3].Well, the first pharmacological study on extracts of the hypobranchial gland of Hexaplex trunculus and Hexaplex brandaris have demonstrated that these extracts displayed in fish a paralyzing action and in dog a fall in blood pressure[4]. Hepatopancreatic phospholipase A2, extracted from Hexaplex trunculus could be considered as an excellent candidate for the development of a new antiinfected agent. This enzyme showed significant anti-microbial activities [5]. Indirubin present in the hypobranchial gland was also an inhibitor of the glycogen syntheses - kinase (GSK-3), with multiple implications in cell death 
signaling, alzheimer disease and signaling pathway of insulin [6]. Visceral mass of fish has been extensively studied over the past 20 years. Those of cephalopods have been little worked. In fact, many researchers were interested in the development of the hepatopancreas of squid [7], in the quality of the viscera of cuttlefish Sepia officinalis [8-9], in the digestive gland of the cuttlefish and in the phospholipase extracted from the hepatopancreas of Hexaplex trunculus [5]. Concerning nutritional and biological activities, there is still limited information on therapeutic properties of the acute Hypobranchial gland of Hexaplex trunculus and Bolinus brandaris. However, these mollusks muricids gastropods present increasing nutritional commercial and economic importance being widely consumed in North Africa particularly in Mediterranean countries including Tunisia. In recent years, their use has intensified acting as a complement to the use of clams Ruditapes decussates [10]. These marine snails are appreciated for their muscles and brown meat content [5]. Like fish, mollusks have a great nutritional value. They are rich in protein [11]. Little is known about the anti-tumor activity of hypobranchial gland of hexaplex. Present therapies, including surgery, radiation therapy and chemotherapy are limited. Effectiveness, malignant glioblastoma is a highest invasive form of brain tumor [12-13]. Finding new therapeutic strategies targeting multiple cells signaling pathways, such as inhibition of proliferation, adhesion, migration, viability and angiogenesis, have been a major point of concern for research in the pharmaceutical sciences.

Despite these preliminary studies, we felt it necessary to determine first nutritional values of edible mix musclehypobranchial gland MHG just contiguous to this brown meat content. We will try to provide as much nutritional information as possible to encourage the farming of the two species and to strengthen the management of their operation so far not controlled. Second, this study attempts, for the first time to characterize and evaluate the effect of hypobranchial glands extracts (HBGE) of Hexaplex trunculus and Bolinus brandaris male and female, on adhesion and cell proliferation of human tumor glioblastoma cells (U87).

\section{Materials and methods}

\subsection{Biological material}

Hexaplex trunculus and Bolinus Brandaris Fig 1 are captured in the coastal region Kalaa El Andalos North East of Tunisia. The animals are washed and kept in seawater. Back to the laboratory, morphometric parameters considered as a reference size adults, are measured using an electronic caliper. The shell is broken with a hammer. Carefully, we remove the soft part of the body. We pick up the fleshy part which constitutes the edible meat and the hypobranchial gland adjoins this muscle. We take again purple glands and meat in a 50ml Falcon tube. Half of the tube is stored at -20 ${ }^{\circ} \mathrm{C}$ for possible nutritional analysis (relative humidity, total ash, fat or lipid, protein, carbohydrate and energy values), the other half is braised. It undergoes a cooking slowly and evenly covered in $5 \mathrm{ml}$ of distilled water on low heat for 15 minutes (temperature $60-70^{\circ} \mathrm{C}$ ). The body cooked is cooled then put in another Falcon tube quickly stored at $-20^{\circ} \mathrm{C}$ for later suffer the same nutritional analysis that fresh uncooked body.

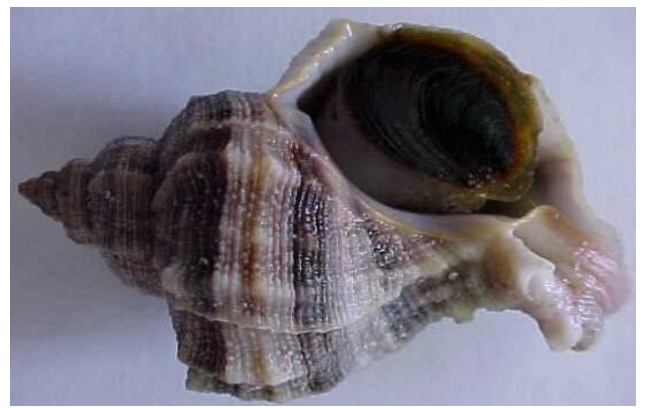

Fig. 1 (A): Hexaplex Trunculus (Linnaeus, 1758) Called Rock Fascinated, Murex or Murex Truncated.

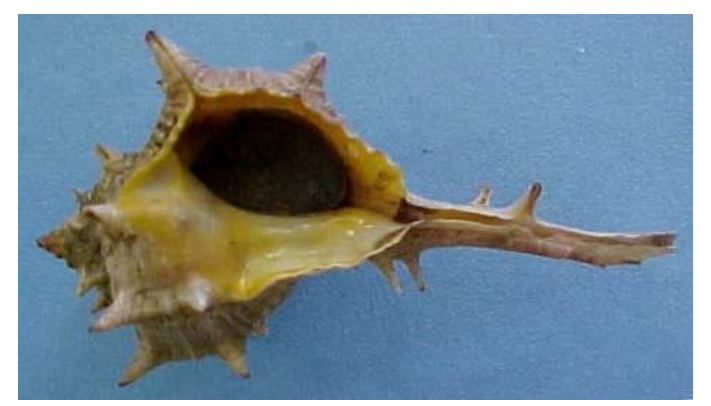

Fig. 1(B): Bolinus Brandaris (Linnaeus, 1758). Called Spiny Rock, Murex Spine, and Murex Purple. These Two Gastropod Mollusks Belonging to The Sub-Family Muricinae, Family Muricidae, Super-Family Muricoidea.

\subsection{Methods of measurement of nutritional values}

Measures of nutritional values were performed using the following methods: baking at $105^{\circ} \mathrm{C}$ for $4 \mathrm{H}$, for relative humidity, (ignition at $900^{\circ} \mathrm{C}$ for 2 hours) for the total ash method [13] for lipids and method [14] for proteins. Carbohydrate and energy values were determined by simple calculation.

\subsection{Cell culture and adhesion assays}

Human glioblastoma (U87) cells were cultured in Minimal culture medium Eagle MEM supplemented with $10 \%$ FBS. Adhesion assays were performed as previously described [10], [11]. Briefly, suspension cells were added to wells coated with purified Extracellular matrix ECM protein: $50 \mu \mathrm{g} / \mathrm{ml}$ fibrinogen (FG) and a synthetic poly-L-lysine (Poly-L) 
$20 \mu \mathrm{g} / \mathrm{ml}$ and were allowed to adhere with the substrate for $1 \mathrm{~h}$ at $37^{\circ} \mathrm{C}$. After washing, attached cells were fixed, stained by $0.1 \%$ crystal violet and lied with $1 \%$ Sodium Dodecyl Sulphate SDS. Absorbance was measured at $560 \mathrm{~nm}$ by a micro plate reader.

\subsection{Cell proliferation}

The effect of tested compounds on proliferation of U87 cell line was determined using the MTT [3 (4,5diméthylthiazol-2-yl)-2,5-diphenyltétrazolium bromide)]assay. The technique used consists in seeding cells U87 in the wells of a microtiter plate at a rate of $5.10^{3}$ cells / well in $50 \mu 1$ of Medium Dulbecco's Modified Eagle DMEM culture milieu. The control cells were maintained in normal medium. $1 \mathrm{H}$ After incubation the medium was renewed in the presence of our four test samples. Daily, 3 wells of each sample were washed with Phosphate Buffer Saline PBS and the cells were fixed in $1 \%$ glutaraldehyde, and stored in PBS. At the end of $5^{\text {th }}$ day, cells were stained with $0.1 \%$ crystal violet and quantified by measuring the absorbance at $560 \mathrm{~nm}$.

\section{Statistical study}

Statistical analyzes were performed using Excel 2007 on a Windows XP software. The statistical tests used are F-test and the Fisher Student test T. This analysis was reinforced by the use of SAS software (1989). The results are expressed as mean emerged from its standard error of the mean (SEM). Biology activity data is expressed at least 3 independent experiments. Statistical differences were evaluated by 1-way ANOVA followed by Turkey's test using commercially available software (SPSS 17.0; SPSS Inc; Chicago, III). P values $<0.05$ were statistically significant.

\section{Results}

\subsection{Relative humidity}

Our results reported in Fig 2, show that fresh MHG- HT male and female $(82.52 \pm 0.56 \% ; 79.23 \pm 0.39 \%)$ respectively are rich in water as MHG-BB male and female $(79.28 \pm 0.43 ; 80.04 \pm 0.26 \%)$ respectively. The difference is not significant between male and female $(\mathrm{p}=0.07)$. Cooking decreases water content male and female in MHG-HT $(64.27 \pm$ $0.64 ; 66.94 \pm 0.78 \%)$ and in MHG-BB $(66.02 \pm 0.73 ; 66.01 \pm 0.35 \%)$ respectively. The difference is significant between fresh and cooked MHG $(\mathrm{p}<0.05)$.

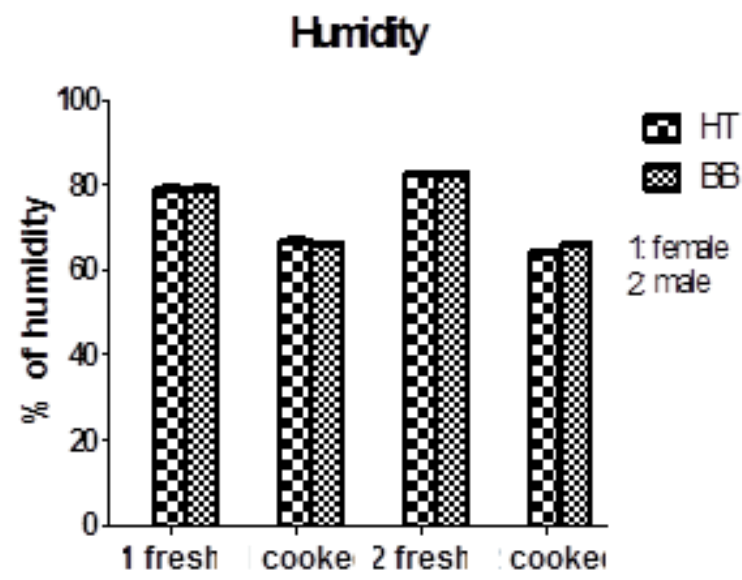

Fig. 2: Relative Humidity in \% (Drying Method at $105^{\circ} \mathrm{C}$ For $4 \mathrm{~h}$ ). 1: Female, 2: Male

\subsection{Total ash or minerals}

Figure 3, shows that minerals are present with small percentages in fresh mix muscle and hypobranchiale gland male and female, HT $(1.11 \pm 0.14 \% ; 1.52 \pm 0.03 \%)$ respectively and also BB $(1.27 \pm 0.17 \% ; 1.07 \pm 0.11 \%)$ respectively. The difference is not significant between male and female $(\mathrm{p}=0.084)$. Cooking increases these low levels of total ash: MHG-HT male and female $(2.04 \pm 0.12 \% ; 2.31 \pm 0.28 \%)$, MHG-BB male and female, $(3.13 \pm 0.16 \% ; 1.93 \pm 0.13 \%)$. The difference is not significant between cooked organs $(\mathrm{p}=0.169)$, but significant between fresh and cooked organs $(\mathrm{p}<0.005)$. 


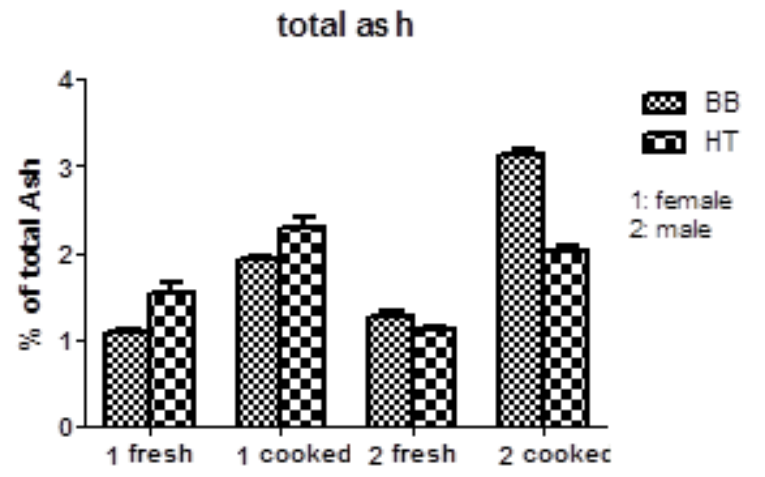

Fig .3: Total Ash in $\%$ (Incineration at $900^{\circ} \mathrm{C}$ For 2h). 1: Female, 2: Male

\subsection{Lipids or fat}

Percentages of fat in fresh MHG-HT female and male $(2.55 \pm 0.37 \% ; 1.80 \pm 0.25 \%)$ are elevated compared to female and male MHG-BB $(0.89 \pm 0.07 \% ; 0.74 \pm 0.09 \%)$ respectively. The difference is significant between HT and BB organs $(\mathrm{p}<0.05)$. Cooking reduces not significantly the fat content of these organs $(\mathrm{p}=0.075)$. Figure4.

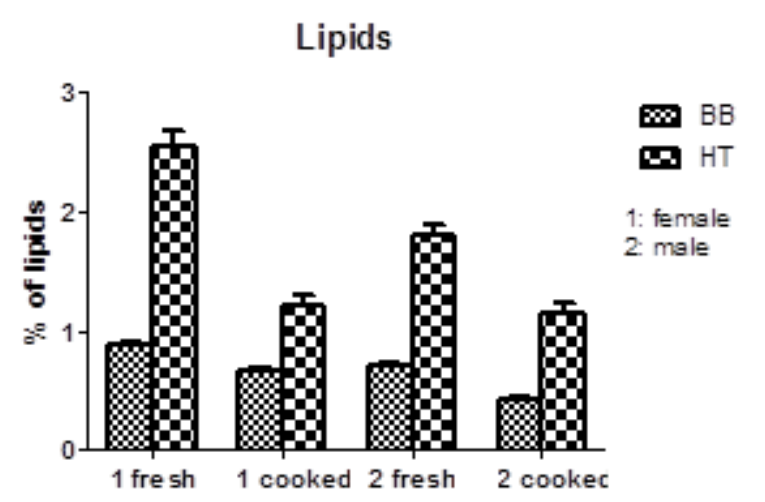

Fig .4: Fat or Lipids in \% (Method of Folch et al 1957). 1: Female, 2: Male

\subsection{Protein}

Protein levels are higher in fresh male and female mixture meat hypobranchiale gland Bolinus Brandaris (12.32 \pm 0.37 ; $12.79 \pm 0.72 \%)$ than Hexaplex trunculus $(10.46 \pm 0.67 ; 10.30 \pm 0.49 \%)$ respectively. The difference is not significant between males and females $(\mathrm{p}=0.079)$. Cooking increases significantly this common protein content $(\mathrm{p}<0.05)$, Figure 5.

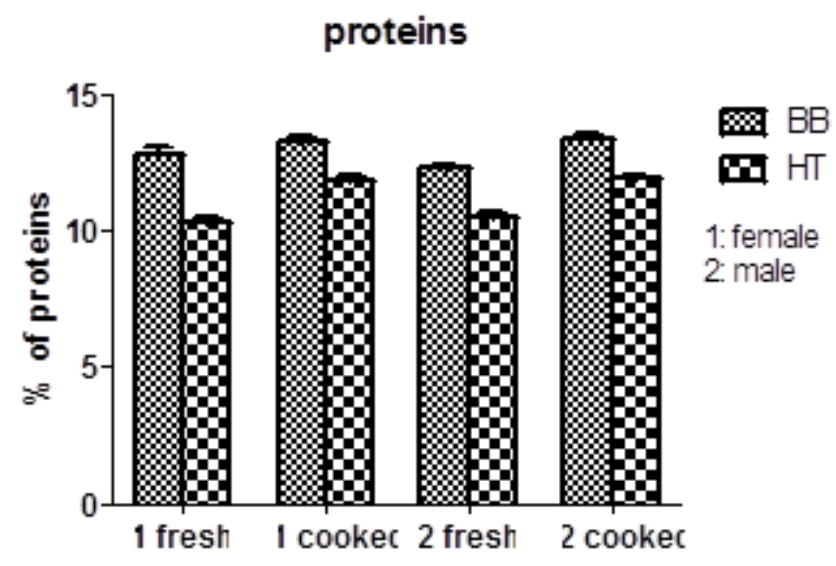

Fig .5: Proteins in \% (Method Crooke Et Al 1971) 1: Female, 2: Male. 


\subsection{Carbohydrates}

Percentages of carbohydrates in fresh female and male MHG-HT $(5.43 \pm 0.44 ; 5.40 \pm 0.42 \%)$ and MHG-BB (5.61 \pm $0.38 ; 6.27 \pm 0.44 \%)$ are less that percentages of proteins about the half. The difference is not significant between all the organs $(\mathrm{p}=0.083)$. Cooking increases slightly these low levels of carbohydrates Figure 6.

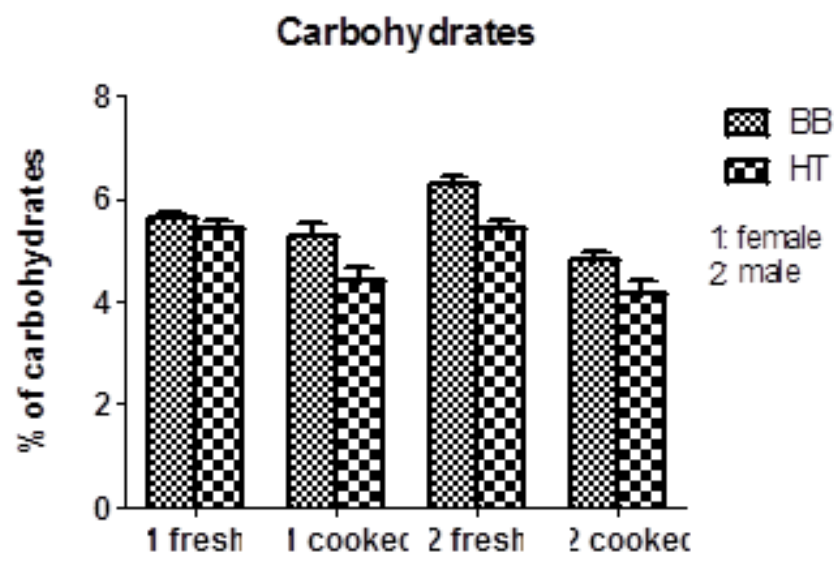

Fig. 6: Carbohydrates in $\%=100 \%$ - $[\%$ Humidity $+\%$ Proteins $+\%$ Total Hash $+\%$ Fat $]$. 1: Female, 2 : Male.

\subsection{Energy value}

Energy values of fresh organs are important in male and female MHG-HT $(69.48 \pm 0.52 ; 93.75 \pm 0.37 \%)$ and MHG-BB too $(78.84 \pm 0.27 ; 79.14 \pm 0.35 \%)$. The difference is not significant between males and females BB ( $\mathrm{p}=0.105)$. Cooking increases significantly the energy value of these organs $(\mathrm{p}<0,005)$ Figure 7.

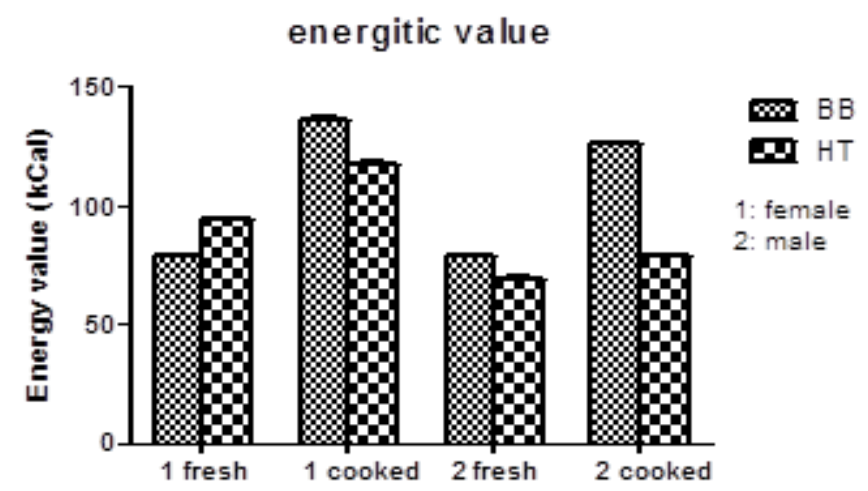

Fig. 7: Energetic Value in Kcal= (4Proteins +4 Carbohydrates +9 Fat $)$. 1: Female, 2: Male

\section{Proteins extraction}

Protein concentrations of our different hypobranchial gland extract (HBGE) of Hexaplex trunculus (HT) and Bolinus brandaris (BB) are presented in Table 1 and used during all experiments.

Table 1: Proteins Concentrations (Mg/Ml) of HBGE Hexaplex Trunculus and Bolinus Brandaris Males and Females.

\begin{tabular}{lll}
\hline Echantillons & Concentration $\mathrm{mg} / \mathrm{ml}$ \\
\hline 1$)$ & HBGE (Hexaplex Trunculus male) & 191,22 \\
$2)$ & HBGE (Hexaplex Trunculus Female) & 204,72 \\
$3)$ & HBGE (Bolinus Brandaris Male) & 188,59 \\
$4)$ & HBGE (Bolinus Brandaris female) & 166,22 \\
\hline
\end{tabular}

\section{Cell adhesion}

In order to investigate the HBGE of HT and BB effects on glioblastoma cell line U87, first, we performed cell adhesion assay using fibrinogen as matrix. As shown in Fig.8A, HBGE of H.T inhibited U87 cell adhesion to fibrinogen at 15 
$\mathrm{mg} / \mathrm{ml}$ dose. This inhibition was significantly impaired at $20 \mathrm{mg} / \mathrm{ml}$ dose of male extract as well as female extract without exceeding $50 \%$ of inhibition. The effect is more accentuated when we used HBGE of Bolinus brandaris mostly male which reduced glioblastoma cells adhesion upon to $5 \mathrm{mg} / \mathrm{ml}$ of protein mixture. This diminution membership significantly continues until the dose $20 \mathrm{mg} / \mathrm{ml}$ in dose dependant manner with $\mathrm{IC}_{50}$ values of approximately $9 \mathrm{mg} / \mathrm{ml}$ for male extract and $20 \mathrm{mg} / \mathrm{ml}$ for female one (p<0.005) (Fig 8B). The HBGE of BB and HT inhibition of U87 cell adhesion to fibrinogen could pass through the integrin family receptors because adhesion of U87 was not significantly affected when using the integrin independent substratum poly-L-lysine ( $\mathrm{p}=0.067)$ (Fig 8C).

A

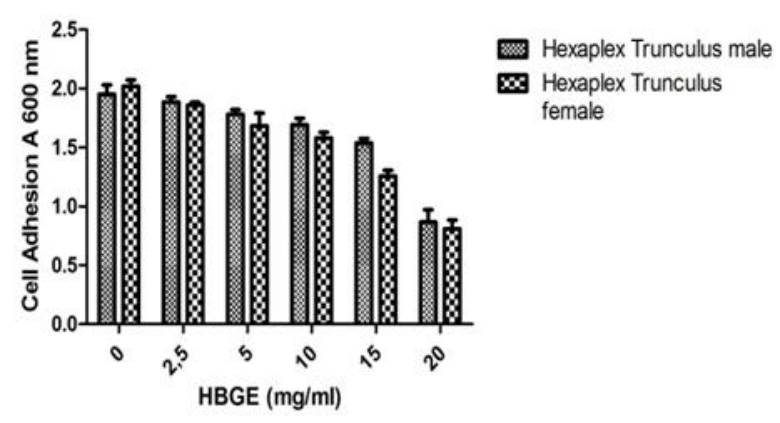

B

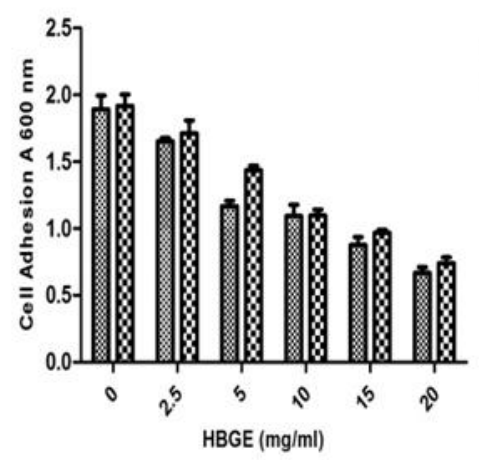

Bolinus Brandaris male

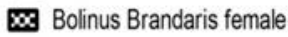

C

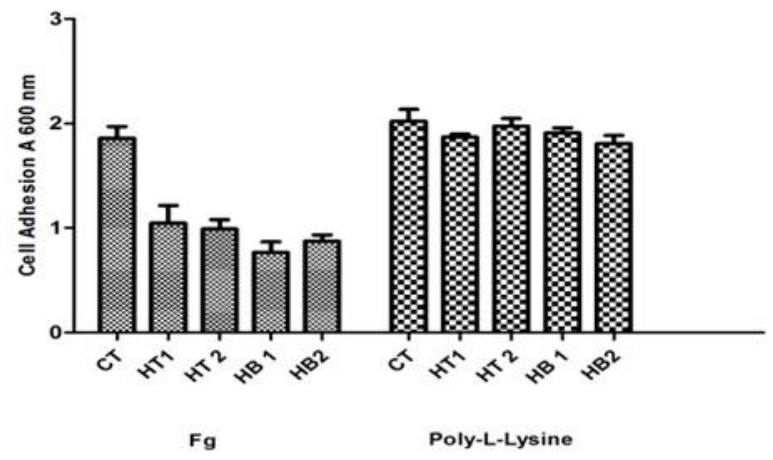

Fig. 8: HBGE Inhibits Human Glioblastoma Cell Adhesion. (A) Glioblastoma Cells U87 Were Pre-Incubated In the Presence of HBGE of Hexaplex Tranculus Male or Female at the Indicated Doses for 30 Min at Room Temperature. (B) Glioblastoma Cells U87 Were Pre-Incubated in the Presence of Male HBGE or in the Presence of Female HBGE at the Indicated Doses Cells were then Added to 96-Well Microtiter Plates Coated with Fibrinogen (Fg).(C) U87 Were Preincubated Without or with 20 Mg/Ml Of HBGE For 30 Min at Room Temperature. Cells Were then Added to 96Well Microtiter Plates Coated with $50 \mu \mathrm{g} / \mathrm{Ml}$ Fibrinogen (Fg) or $20 \mu \mathrm{g} / \mathrm{Ml}$ Poly-L-Lysine (PLL) and Allowed to Adhere for $1 \mathrm{H}$ At $37^{\circ} \mathrm{C}$. after Washing, Adherent Cells Were Fixed, Stained with Crystal Violet, Solubilized By SDS and Absorbance was Measured at $600 \mathrm{Nm}$.

\section{Cell proliferation}

Our study shows for the first time that HBGE of Hexaplex trunculus, Bolinus brandaris present and interesting antitumour activity. They are able to inhibit adhesion of U87 glioblastoma cell line towards fibrinogen taken as extracellular matrix. To complete the study of these activities, we found it useful to test the proliferation of U87 cells incubated for 5 days in the presence of four samples at $5 \mathrm{mg} / \mathrm{ml}$ concentration.

By referring to the Fig.9A, our results show that U87 cells treated with HBGE of Hexaplex trunculus inhibited significantly cell proliferation by $50 \%$. This inhibition is more pronounced when cancer cells are treated with females 
HBGE and reaching 70\%. U87 cells treated with both male and female HBGE of Bolinus brandaris decreased proliferation significantly after 5 days incubation by more than $90 \%(\mathrm{p}<0.05)$ Fig.9B.

A

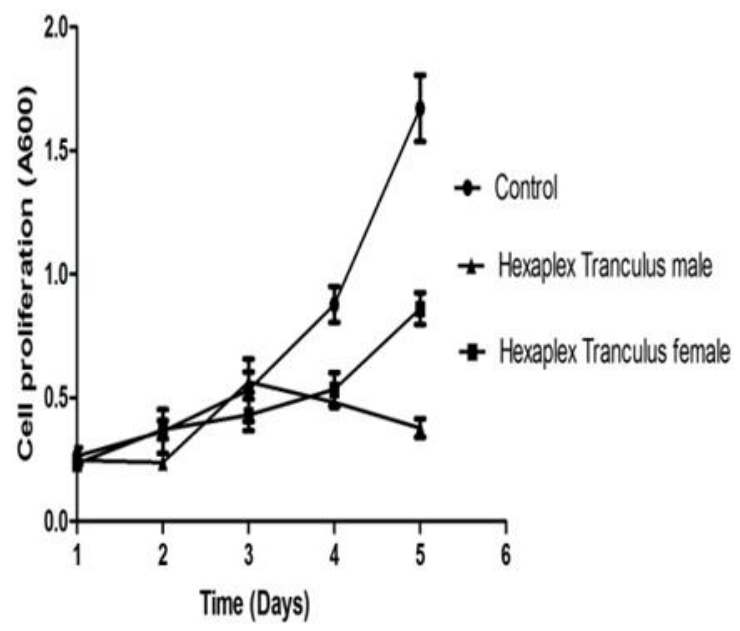

B

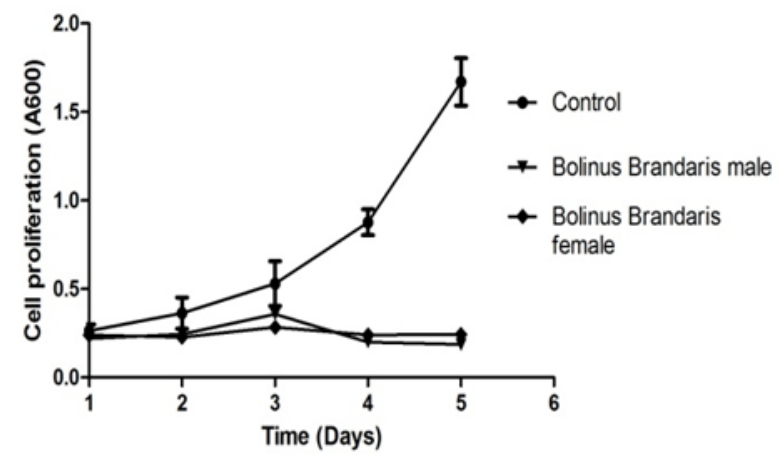

Fig. 9: HBGE Inhibits Tumour Cells Proliferation. U87 Cells Were Cultured for The Indicated Periods of Time in the Absence or in The Presence Of $2.5 \mathrm{Mg} / \mathrm{Ml}$ Of HBGE of Hexaplex Trunculus (A) and Hexaplex Brandaris (B) Cell Proliferation Activity was Evaluated By Using Crystal Violet Staining. Measurement of the Absorbance Was Performed at A Wavelength of $560 \mathrm{Nm}$. the Results are From A Representative Experiment of Two Performed in Triplicate.

\section{Discussion}

Our study shows that the edible internal organs mix (muscle-hypobranchiale gland) of Hexaplex trunculus and Bolinis brandaris are rich in water, protein but less in minerals, fat, carbohydrates. They have substantial energy values too. In fact, a large quantity of water content is found in both male and female fresh MHG- HT $(82.52 \pm 0.56 \% ; 79.23 \pm 0.39$ $\%)$ and MHG-BB $(79.28 \pm 0.43 ; 80.04 \pm 0.26 \%)$ respectively. These results correlate with those found in viscera cuttlefish captured in the Gulf of Gabes (south Tunisia) which are composed from $80 \%$ of water (79\% in the viscera with ink and $75 \%$ for the viscera without ink) [15]. Ink of fresh sepia officinalis contains less water $65.54 \%$ only [16].This ink is composed mainly of water and other volatiles and organic substances and mineral substances [17]. The high water content of the joint liquid product is used during its ejection in the presence of a predator constituting a smoke that the animal uses to hide or escape [18]. However, The richness of water in all fresh muscles HT and BB can be explained by more intense metabolic activity of muscle cells consuming relatively large amount of water to ensure the slowly movement of these heavy gastropods mollusks.

Mineral content is low in all MHG male and female HT $(1.11 \pm 0.14 \% ; 1.52 \% \pm 0.03)$ and BB $(1.27 \% \pm 0.17 ; 1.07 \pm$ $0.11 \%$ ) respectively. These values are less than found in total ashes of cuttlefish viscera which vary around 7\% [15]. In the same way, the percentage of minerals in fresh sepia officinalis ink (liquid viscera) was 5.78\% [16]. Accumulation of minerals in squid ink can be explained by the fact that these salts are contained in the amorphous structure of this black substance. [19]. The presence of a low level of minerals in the edible portion of these gastropods is probably due to the muscular nature of this internal organ low in trace elements.

Lipids of fresh organs are accumulated with the same less percentages for males and females MHG BB $(0.74 \pm 0.09$; $0.89 \pm 0.07 \%)$ respectively. They are more important in MHG HT $(1.80 \pm 0.25 ; 2.55 \pm 0.37 \%)$ respectively. This low lipid content was also observed in fresh ink of Sepia officinalis only $0.18 \%$ [15]. However, Accumulation of lipids was 
observed in Hexaplex trunculus Hepatopancreas where the percentage of polyunsaturated fatty acids was $68.2 \%$. Saturated fatty acid represented only $33.4 \%$ [5]. These results correlate with those found in the hepatopancreas of the cuttlefish where the rate of C16: O was $19.23 \%$ [20]. Solid viscera of Sepia officinalis have a lipid content $4.8 \pm 0.7 \mathrm{~g}$ $/ 100 \mathrm{~g}$ of fresh material distributed in $40 \%$ of saturated fatty acid and $36.39 \%$ mono-insatureted fatty acid. The $\omega 3$ acids represented $52 \%$ of the total fatty acids of the viscera[15]. Whatever, high or low percentage of fat contained in the various internal organs of marine mollusks are rich in polyunsaturated fatty acids and contribute at the prevention of atherosclerosis through their antioxidant action. They also play a role in the prevention of aging; promote healthy growth and good development fetus and infant. Polyunsaturated fatty acid family $\omega 3$ present in lipid fraction is potentially important and have been widely described in the literature. [21].

Our study shows that edible internal organs males and females of Hexaplex trunculus and Bolonis brandaris are rich in proteins with percentages ranging from $12.79 \pm 0.72 \%$ in the female MHG BB to $10.30 \pm 0.49 \%$ in the female MHG HG. These results are consistent with those worked in the same marine gastropod Hexaplex trunculus [5]. All edible tissues were valuable sources of essential amino acids. Aspartic acid is the major amino acids present in the meat and hepatopancreas of Hexaplex trunculus. The protein fraction in the fresh ink of Sepia officinalis was (15.75\%), where the essential amino presented $40 \%$ of phenylalanine [16]. Similarly, other results showed that protein content of cuttlefish viscera was $17.6 \pm 0.3 \mathrm{~g} / 100 \mathrm{~g}$ dry matter. The essential amino acids in these organs were $36 \%$ of phenylalanine too[15]. In addition, viscera are the seat of increased enzyme activity playing an important role in physiological nutritional of these internal organs. Rapid growth and protein metabolism predominantly involves a high protein turnover and therefore significant proteolyses activities [21-22].

The increase in protein content observed by the effect of cooking is probably due to the hydrolysis of proteins and the release of amino acids by the effect of heat.

As for lipids, fresh MHG male and female are also not rich in carbohydrates $(5.40 \pm 0.42 ; 5.43 \pm 0.44 \%)$ for HT and $(6.27 \pm 0.44 ; 5.61 \pm 0.35)$ for $\mathrm{BB}$ respectively. However, concentration of carbohydrate was also determinate in the hepatopancreas more than in meat of Hexaplex trunculus [5]. Richness of hepatopancreas in carbohydrate could be explained by the important role of this organ in the storage of carbohydrate nutrient as liver in vertebrates. Since the meat part is generally rich in protein, his carbohydrate content is less important: $12.32 \%$ protein, $6.27 \%$ carbohydrate for BB and $10.46 \%$ protein, $5.43 \%$ carbohydrate for HT. Nidamental glands use these carbohydrates to form and to protect gel of eggs [23]. Chemical composition of carbohydrates in fresh ink of sepia officinalis was estimated at $13.75 \%$. Polysaccharides extracted formed $3.02 \%$ and presented a significant anti-mutagenic activity. Also $0.8 \%$ of carbohydrates in the ink of Octopus vulgarus contained in melanin participated at the inhibition of gastric secretion and the prevention of pyloric ulcer in rats.[24].

The richness more or less important in protein, lipids and carbohydrate in the whole edible muscle -purple gland extract from internal organs of Hexaplex trunculus and Bolinus brandaris males and female gives a substantial energy values ranging from $79.14 \pm 0.35 \mathrm{kcal}$ in $\mathrm{MHG}-\mathrm{BB}$ fresh female to $69.48 \pm 0,42 \mathrm{kcal}$ in $\mathrm{MHG}-\mathrm{HT}$ fresh female. These values allow us to encourage the consumption of mix muscle- purple gland of these marine snails not yet well known. The purple gland of gastropods muricids was mainly studied for its appearance and color in painting, especially in dyeing noble clothes [25]. Little work has been done on the biochemical and pharmacological effects of this gland fine and difficult to handle. It is in this context that integrates our work focusing on the evaluation of protein extracts from hypobranchials glands of Hexaplex trunculus and Bolinus brandaris. We also investigated if this evaluation can be influenced by the sex of the mollusks. Protein extraction of this gland has shown that all the supernatants are rich in protein. First, cell adhesion is a critical process in many biological phenomena, such as tumor development and metastasis [26]. Our findings clearly show for the first time, that hypobranchial gland extract of both sexes of Hexaplex trunculus inhibited U87 cell adhesion to fibrinogen at $15 \mathrm{mg} / \mathrm{ml}$ dose and was significantly accelerated at $20 \mathrm{mg} / \mathrm{ml}$ $(\mathrm{p}<0.05)$. This effect is more accentuated when we used HBGE of Bolinus brandaris witch abolished glioblastoma cells adhesion upon to $10 \mathrm{mg} / \mathrm{ml}$ of protein mixture. This diminution membership significantly continues until the dose of 20 $\mathrm{mg} / \mathrm{ml}(\mathrm{p}<0.005)$. These very high doses in the order of $\mathrm{mg} / \mathrm{ml}$, can be explained by the wealth of theses hypobranchial glands in proteins [5]. Inhibition's U87 cell adhesion to fibrinogen by HBGE of HT and BB likely involved the integrin family of adhesion receptors. In fact, we have observed no significant effect of U87 adhesion when we have used the integrin independent substratum poly-L-lysine $(\mathrm{p}=0.05)$. Working on the anti-tumoral marine product, our results are consistent with the crude venom of jellyfish Pelagia noctiluca witch had no effect on the adhesion of U87 when they used the integrin independent substratum poly-L-lysine. They hypothesized that crude venom could affect the function of this family of adhesion receptors [27]. Preclinical data indicate that integrins play a key role in cancer initiation and progression [28]. They are primarily responsible for cell adhesion to the extra cellular matrices ECM and are involved in anchorage- dependent cell proliferation [29], [30]. The integrins alphaV beta3 and alphaV beta5 are expressed not only on the tumor vasculature and angiogenic endothelial cells, but also on tumor cells, including glioblastoma [31]. In gliobastoma, over expression of alphaV beta 3 integrin is well documented. Importantly immuno-histochemistry analysis revealed that alphaV beta3 integrin expression was mainly confined to the tumor region and was absent in normal tissue [32]. One of the most frequent parameters assessed in cancer drugs discovery is the impact of cancer cells proliferation [33]. For this reason, the effect of HBGE of Hexaplex trunculus, Bolinus brandaris on U87 cell proliferation were assessed, over a concentration of $5 \mathrm{mg} / \mathrm{ml}$. Our results have shown that U87 cells treated with (HBGE) of HT and BB decreased significantly proliferation after 5 days incubation $(\mathrm{p}<0.05)$. Similar to our results, anti-proliferative activity rates of Jellyfish's venom fractions appear to be very interesting since it exhibit an anti- 
proliferative effect comparable to that of the drug used clinically for tumour treatment [27]. Cryptophycins, examples of marine cyanobacteria-derived tubuling-binding compounds are also potent anti-proliferative and anti-mitotic agents [34]. However, this diminution of cell proliferation has not been demonstrated in the study of anti-tumour activity of some ink marine cephalopods. In fact it has been demonstrated that the squid ink of Ommastrephes bartrami has no obvious effects on the proliferation of tumour cells Hep G2 but induces dose-dependent suppression of cell invasion and migration [35].

\section{Conclusion}

Comparative study of nutritional values of the edible mix Muscle - Hypobranchial Gland MHG fresh or cooked extract from internal organs of Hexaplex trunculus HT and Bolinus brandaris BB males and females, shows that these organs contain valuable nutritional values with generally non-significant difference between male and female. Biochemical analyzes prove that fresh MHG HT and BB are rich in Water, in Proteins and in Energy value too. They contain fewer carbohydrates, less total ash and lipids. Sex and cooking over low heat, have generally no significant effect on these nutritionals values. These results lead us to encourage the use of these marine snails, source of protein and high energy values. Moreover, mix edible muscle- hypobranchial gland of these gastropods also contain lipids wish probably can reduce the incidence of certain diseases. In fact, hypobranchial glands HBGE of HT and BB inhibited glioblastoma cell adhesion and proliferation. These inhibitions are probably reliant on its ability to interact with integrins. Although, the specific integrins affected by HBGE have not been identified in this study. The integrin alpha v beta 3 and alpha 5 betas 1 might be involved. The purification and the determination of chemical structures of these active molecules are under investigation. HBGE of HT or BB may have the potential to serve as a template for future anticancer-drug development. Further analyses are warranted and necessary to substantiate our findings.

\section{Acknowledgements}

This work is supported by the laboratory of venoms and therapeutic biomolecules Pastor Institute of Tunis and the laboratory of Nutritional Analysis, National Institute of Nutrition and Food Technology of Tunis as part of collaboration between these Institutes and the National Institute of Applied Sciences and Technology (Research Unit of industrial organic chemistry and food).

\section{References}

[1] Bouchilloux, S. and J. Roche, [Murex purple and its precursors]. C R Seances Soc Biol Fil, 1954. 148(19-20): p. 1580-3.

[2] Clarke, A., et al., Growth-Rate and Nucleic-Acid Ratio in Cultured Cuttlefish Sepia-Officinalis (Mollusca, Cephalopoda). Journal of Experimental Marine Biology and Ecology, 1989. 133(3): p. 229-240. http://dx.doi.org/10.1016/0022-0981 (89)90047-6.

[3] Roseghini, M., et al., Choline esters and biogenic amines in the hypobranchial gland of 55 molluscan species of the neogastropod Muricoidea superfamily. Toxicon, 1996. 34(1): p. 33-55. http://dx.doi.org/10.1016/0041-0101 (95)00104-2.

[4] Koren, Z.C., The First Optimal All-Murex All-Natural Purple Dyeing in the EasternMediterranean in a Millennium and a Half Dyes in History and Archaeology, 2005. 20: p. 136-149.

[5] Zarai, Z., et al., Antibacterial, anti-chlamydial, and cytotoxic activities of a marine snail (Hexaplex trunculus) phospholipase A2: an in vitro study. Appl Biochem Biotechnol, 2012. 168(4): p. 877-86. http://dx.doi.org/10.1007/s12010-012-9826-1.

[6] Roseghini, M., et al., Choline esters and biogenic amines in the hypobranchial gland of 55 molluscan species of the neogastropod Muricoidea superfamily. Toxicon, 1996. 34(1): p. 33-55. http://dx.doi.org/10.1016/0041-0101 (95)00104-2.

[7] Balti, R., et al., Cathepsin D from the hepatopancreas of the cuttlefish (Sepia officinalis): purification and characterization. J Agric Food Chem, 2010. 58(19): p. 10623-30. http://dx.doi.org/10.1021/jf102233d.

[8] Le Bihan, E., A. Perrin, and N. Koueta, Effect of different treatments on the quality of cuttlefish (Sepia officinalis L.) viscera. Food Chemistry, 2007. 104(1): p. 345-352. http://dx.doi.org/10.1016/j.foodchem.2006.11.056.

[9] Mai, K.L.H., et al., Effects of dietary squid viscera meal on growth and cadmium accumulation in tissues of Japanesse seabass, Lateolabrax japonicus (cuvier 1828) Aquaculture Res, 2006. 37: p. 1063-1069. http://dx.doi.org/10.1111/j.1365-2109.2006.01529.x.

[10] Lahbib, Y., et al., First record of butyltin body burden and imposex status in Hexaplex trunculus (L.) along the Tunisian coast. J Environ Monit, 2009. 11(6): p. 1253-8. http://dx.doi.org/10.1039/b822102b.

[11] Barrento, S., et al., Chemical composition, cholesterol, fatty acid and amino acid in two populations of brown crab Cancer pagurus Ecological and human health implications. Journal of Food Composition and Analysis, 2010. 23(7): p. 716-725. http://dx.doi.org/10.1016/j.jfca.2010.03.019.

[12] Wong, M.L., A.H. Kaye, and C.M. Hovens, Targeting malignant glioma survival signalling to improve clinical outcomes. J Clin Neurosci, 2007. 14(4): p. 301-8. http://dx.doi.org/10.1016/j.jocn.2006.11.005.

[13] Folch J, Lees M and Sloane Stanley GH. A simple method for the isolation and purification of total lipides from animal tissues. J Biol Chem, 1957. 226(1): p. 497-509.

[14] crooke W M, Simpson W E. Determination of ammonium in Kjeldhal digests of crops by an automated procedure. J.Agric.Food chemestery, 1971.Vol. 27: p. 1256-1262.

[15] Kechaou, E.S., et al., Enzymatic hydrolysis of cuttlefish (Sepia officinalis) and sardine (Sardina pilchardus) viscera using commercial proteases: effects on lipid distribution and amino acid composition. J Biosci Bioeng, 2009. 107(2): p. $158-64$. http://dx.doi.org/10.1016/j.jbiosc.2008.10.018.

[16] Neifar, A., et al., Physicochemical characterization of Sepia officinalis ink and the effects of storage conditions on the coagulation process. Journal of the Marine Biological Association of the United Kingdom, 2009. 89(4): p. 803-807. http://dx.doi.org/10.1017/S0025315408002798.

[17] Brackman, W. and E. Havinga, O.Diphenol formation from phenol without enzyme. Rec Trav chim des Pays-Bas, $1955.74:$ p. 1107. 
[18] Adamo, S.A., et al., Signaling to the enemy? Body pattern expression and its response to external cues during hunting in the cuttlefish Sepia officinalis (Cephalopoda). Biol Bull, 2006. 210(3): p. 192-200. http://dx.doi.org/10.2307/4134557.

[19] doguzhaeva, L.A., R.H. Mapes, and H. Mutvei, The shell and ink sac morphology and ultrastructure of the late pennsylvanian cephalopod and Donovaniconus and its phylogenetic signficance. berliner palaobiol Abh, 2003. 3: p. 61-78.

[20] Shyla, G., et al., Liver oil of pharaoh cuttlefish Sepia pharaonis Ehrenberg, 1831 as a lipid source in the feed of giant freshwater prawn, Macrobrachium rosenbergii (De Man 1879). Aquaculture Nutrition, 2009. 15(3): p. 273-281. http://dx.doi.org/10.1111/j.13652095.2008.00592.x.

[21] Perrin, A., E. Le Bihan, and N. Koueta, Experimental study of enriched frozen diet on digestive enzymes and growth of juvenile cuttlefish Sepia officinalis L. (Mollusca Cephalopoda). Journal of Experimental Marine Biology and Ecology, 2004. 311(2): p. 267-285. http://dx.doi.org/10.1016/j.jembe.2004.05.012.

[22] Balti, R., et al., Comparative Study on Biochemical Properties and Antioxidative Activity of Cuttlefish (Sepia officinalis) Protein Hydrolysates Produced by Alcalase and Bacillus licheniformis NH1 Proteases. J Amino Acids, 2011. 2011: p. 107179.

[23] Nair, J. R. Cephalopod research and bioactive substances. Indian Journal of Geo-Marine Sciences, 2011. 40(1): p. 13-27.

[24] Vaz-Pires,P. Barboza,A, sensory, micribiological, physiology and nutritional propertes in iced whole common octopus (Octopus vulgatis), 2004 Lebensm Wiss.u- Technol Vol. 37; p 105-114

[25] Koren, Z.C., The First Optimal All-Murex All-Natural Purple Dyeing in the EasternMediterranean in a Millennium and a Half Dyes in History and Archaeology, 2005. 20: p. 136-149.

[26] Hynes, R.O., et al., toward a genetic analysis of cell-matrix adhesion. Cold Spring Harb Symp Quant Biol, 1992. 57: p. 249-58. http://dx.doi.org/10.1101/SQB.1992.057.01.030.

[27] Ayed, Y., et al., Impairment of the cell-to-matrix adhesion and cytotoxicity induced by the Mediterranean jellyfish Pelagia noctiluca venom and its fractions in cultured glioblastoma cells. Lipids Health Dis, 2012. 11: p. 84. http://dx.doi.org/10.1186/1476-511X-11-84.

[28] Desgrosellier, J.S. and D.A. Cheresh, Integrins in cancer: biological implications and therapeutic opportunities. Nat Rev Cancer, 2010. 10(1): p. 9-22. http://dx.doi.org/10.1038/nrc2748.

[29] Braud, S., et al., The contribution of residues 192 and 193 to the specificity of snake venom serine proteinases. J Biol Chem, 2000. 275(3): p. 1823-8. http://dx.doi.org/10.1074/jbc.275.3.1823.

[30] Cruet-Hennequart, S., et al., alpha (v) integrins regulate cell proliferation through integrin-linked kinase (ILK) in ovarian cancer cells. Oncogene, 2003. 22(11): p. 1688-702. http://dx.doi.org/10.1038/sj.onc.1206347.

[31] Ruegg, C., et al., The quest for surrogate markers of angiogenesis: a paradigm for translational research in tumor angiogenesis and antiangiogenesis trials. Curr Mol Med, 2003. 3(8): p. 673-91. http://dx.doi.org/10.2174/1566524033479410.

[32] Schnell, O., et al., Imaging of integrin alpha (v) beta (3) expression in patients with malignant glioma by [18F] Galacto-RGD positron emission tomography. Neuro Oncol, 2009. 11(6): p. 861-70. http://dx.doi.org/10.1215/15228517-2009-024.

[33] Beer, A.J., et al., Positron emission tomography using [18F]Galacto-RGD identifies the level of integrin alpha(v)beta3 expression in man. Clin Cancer Res, 2006. 12(13): p. 3942-9. http://dx.doi.org/10.1158/1078-0432.CCR-06-0266.

[34] Griffiths, M. and H. Sundaram, Drug design and testing: profiling of antiproliferative agents for cancer therapy using a cell-based methyl[3H]-thymidine incorporation assay. Methods Mol Biol, 2011. 731: p. 451-65. http://dx.doi.org/10.1007/978-1-61779-080-5_36.

[35] Lu, J., F. Chen, and R.E. Hodson, Distribution, isolation, host specificity, and diversity of cyanophages infecting marine Synechococcus spp. in river estuaries. Appl Environ Microbiol, 2001. 67(7): p. 3285-90. http://dx.doi.org/10.1128/AEM.67.7.3285-3290.2001. 